\title{
How patient's access to evidence-based medicine provides them with a new hope"The 45 min-an insightful round"
}

\section{Imbesat Maheen Syed}

10.1136/bmjebm-2019-111164

Correspondence to: Dr Imbesat Maheen Syed, Surgery/Pediatric Surgery, Private, Karachi, Sindh, Pakistan; Dr. imbesatmaheen@live.com

\section{Check for updates}

(1) Author(s) (or their employer(s)) 2020. No commercial re-use. See rights and permissions. Published by BMJ.

To cite: Syed IM. BMJ Evidence-Based Medicine 2020;25:117.
I am a medical officer leading a team of two students, a nurse and an inhouse doctor for what seems to be a typical ward round. We are seeing some patients who have just been moved under the care of our team in an oncology unit.

While on the round, one of my patients needs the nurse, who promptly leaves to attend to the call. As we move on, the students also leave for a class. The inhouse doctor soon requests to leave as well. I am beginning to take all this as a sign of something insightful to come.

I am left to see the next patient by myself. I see her as another patient who needs medical attention until we get into a conversation that is both remarkable and, as I have foreseen my day to be, insightful. In mere $45 \mathrm{~min}$, my encounter with this patient will leave an extraordinary impact on the way I interact with other patients.

And so the 45 minutes begin

I inquire about her well-being and get a vague response from her. As I am taking notes in her file, she breaks the ice and asks about details regarding her medical condition. Though this is my first interaction with her, as per her record, she has been admitted for a while but yet, to my surprise, she has not got the answers that she has been seeking. Her record clearly states a disease that does not have a very good prognosis. It is something no one would wish on their worst enemy. She was suffering from a high-grade carcinoma; survival of which beyond 5 years was unusual.

She further tells me that no one has told her anything about her diagnosis; and that in previous rounds, doctors would speak in medical jargon and were too busy discussing her condition with each other to talk to her.

She is inquisitive about the truth and anxious about my answer.

I break down the medical condition and prognosis to make it as simple as possible without omitting any major details. I let her know very clearly the statistics relevant to her disease. My response is purely evidence-based, and I leave no room for subjectivity in what is her personal journey with herself and her faith. I let her be the judge of her own prognosis. Interestingly (and paradoxically) enough, all her anxiety and apprehension that she has been harbouring a moment ago, resolves almost instantaneously. The storm in her had calmed.
In this red-hot minute, she decides that she is ready for recovery and healing. She is so strong in this moment. She tells me that during her hospital stay she has not let her children visit her, but is now going to call them and let them visit. She wants them to be part of her journey to recovery and gain strength from it. She wants to teach them the essential lesson of going with the flow of life.

During this insightful conversation, we talk about the beauty of life, and how there is so much to appreciate in every moment. She tells me that she is into crafts, so instead of lying in bed all day, she would like to knit and crochet and give proceedings for charity. In a heartbeat, a person we thought was in need of help is so overflowing with life that she has now become a 'giver'.

We must give our patients a chance to live. Sometimes, poor choice of words can extinguish their hope and doom them to death, even when it may be evitable. The fine balance is in not giving them false hope, all the while avoiding, limiting them to a particular statistic. Lay out the details for them and some might just decide to 'live'.

During the next few weeks, she makes a 'remarkable recovery'.

I am now rotating in a different unit. To this day, I still hope she is living her life to the full somewhere

Contributors IMS is the sole author of the article. Competing interests None declared.

Patient consent for publication Not required.

Provenance and peer review Not commissioned; internally peer reviewed.

\section{ORCID iD}

Imbesat Maheen Syed http://orcid.org/00000002-5338-8681

\section{References}

1. Chi GC. The role of hope in patients with cancer. Oncol Nurs Forum 2007;34:415-24.

2. AHA finds patient access to medical records higher than ever. http://www.healthcareitnews.com/news/aha-findspatient-access-medical-records-higher-ever

3. https://patientengagementhit.com/features/how-patienthealth-data-access 